\title{
Determination of DNA damage and telomerase activity in stanozolol-treated rats
}

\author{
MEHTAP KARA $^{1 *}$, EREN OZCAGLI ${ }^{1 *}$, PERSEFONI FRAGKIADAKI $^{2}$, TUGBA KOTIL $^{3}$, \\ POLYCHRONIS D. STIVAKTAKIS ${ }^{2}$, DEMETRIOS A. SPANDIDOS ${ }^{4}$, \\ ARISTIDES M. TSATSAKIS ${ }^{2}$ and BUKET ALPERTUNGA ${ }^{1}$
}

\author{
${ }^{1}$ Department of Pharmaceutical Toxicology, Faculty of Pharmacy, Istanbul University, Istanbul 34116, Turkey; \\ ${ }^{2}$ Center of Toxicology Science and Research, Medical School, University of Crete, Heraklion 71003, Greece; \\ ${ }^{3}$ Department of Histology and Embryology, School of Medicine, Istanbul University, Istanbul 34116, Turkey; \\ ${ }^{4}$ Laboratory of Clinical Virology, Medical School, University of Crete, Heraklion 71003, Greece
}

Received September 8, 2016; Accepted December 2, 2016

DOI: $10.3892 /$ etm.2016.3974

\begin{abstract}
Anabolic androgenic steroids (AAS) are performance-enhancing drugs commonly abused by atheletes. Stanozolol is a synthetic testosterone-derived anabolic steroid. Although it is well known that AAS have several side-effects, there are only few toxicological studies available on the toxic effects and mechanisms of action of stanozolol. The aim of this study was to investigate the genotoxic effects of stanozolol and to determine its effects on telomerase activity in Sprague-Dawley male rats. For this purpose, 34 male rats were divided into 5 groups as follows: i) the control group $(n=5)$; ii) the propylene glycol (PG)-treated group $(\mathrm{n}=5)$; iii) the stanozolol-treated group $(\mathrm{n}=8)$; iv) the $\mathrm{PG}$-treated group subjected to exercise $(\mathrm{n}=8)$; and $\mathrm{v}$ ) the stanozolol-treated group subjected to exercise $(n=8)$. PG is used as a solvent control in our study. Stanozolol $(5 \mathrm{mg} / \mathrm{kg})$ and PG $(1 \mathrm{ml} / \mathrm{kg})$ were injected subcutaneously 5 days/week for 28 days. After 28 days, the animals were sacrificed, and DNA damage evaluation (comet assay) and telomerase activity assays were then performed using peripheral blood mononuclear cells (PBMCs). Telomerase activity was measured by using the TeloTAGGG Telomerase PCR ELISA PLUS kit. The results of this study revealed that stanozolol treatment induced DNA damage, while exercise exerted a protective effect. Stanozolol treatment without exercise stimulation was
\end{abstract}

Correspondence to: Professor Buket Alpertunga, Department of Pharmaceutical Toxicology, Faculty of Pharmacy, Istanbul University, Beyazit, Istanbul 34116, Turkey

E-mail: tunga@istanbul.edu.tr

*Contributed equally

Abbreviations: AAS, anabolic androgenic steroids; EB, ethidium bromide; LMA, low melting agarose; NMA, normal melting agarose; PBMCs, peripheral blood mononuclear cells; SD, standard deviation; WADA, World Anti-Doping Agency

Key words: anabolic androgenic steroids, stanozolol, telomerase activity, DNA damage, comet assay associated with a significant increase in telomerase activity in the PBMCs.

\section{Introduction}

Anabolic androgenic steroids (AAS) are synthetic testosterone derivatives, which are widely abused by athletes for enhancing performance and psychological well-being $(1,2)$. These drugs have been abused for many years by athletes and teenagers for the purpose of performance enhancement $(3,4)$.

The chemical structure of steroids, dosage and usage frequency are the main factors responsible for the long-term side-effects of AAS. At supraphysiological doses, several side-effects have been reported due to the use of AAS. These effects include the disruption of lipid metabolism, high blood pressure, cardiac disorders, testicular atrophy, erectile dysfunction, impotence, decreased sex hormone levels, menstrual irregularities, clitoral enlargement, peliosis hepatis, neoplasia, cholestasis, jaundice, acne, alopecia, aggressiveness, depressive symptoms, manic symptoms and psychosis (5). According to worldwide testing data, it has been demonstrated that testosterone, nandrolone, methandienone and stanozolol are the most commonly abused steroids (6).

Stanozolol is a synthetic $17 \alpha$-alkylated derivative of testosterone, with slow hepatic degradation (7). It is medically used for the treatment of anemia and hereditary angioedema (8). Stanozolol has the largest anabolic/androgenic ratios (9). It is known that stanozolol abuse causes a wide range of adverse effects (10). The 'Association of Racing Commissioners International' classified stanozolol as a class III drug (11). According to the '2016 Prohibition List' prepared by the World Anti-Doping Agency (WADA), stanozolol is classified as class S1.1a and it has been prohibited both in and out of competition (12). However, due to the widespread usage of stanozolol, its metabolites have been found to be present in $50 \%$ of positive doping cases $(10,13)$. 3'-Hydroxystanozolol, $4 \beta$-hydroxystanozolol and $16 \beta$-hydroxystanozolol are the main three metabolites of stanozolol. The acceptable urinary concentrations of stanozolol and/or its metabolites are restricted to a maximum of $2 \mathrm{ng} / \mathrm{ml}$ (13). The consumption steroid hormone 
drugs is associated with toxicity, mutagenicity, genotoxicity and cancerogenesis, depending on several factors, including genetic and epigenetic modifications (14). Torres-Bugarín et al reported micronucleus $(\mathrm{MN})$ frequency increase in buccal mucosa cells from bodybuilders who abused AAS (15). However, Hana et al indicated that testosterone synthetic derivatives had no genotoxic effects on mouse germ cells (16). Controversial results have been obtained regarding the genotoxic effects of steroids $(17,18)$.

Telomeres play a key role in cell aging and DNA damage mechanisms. The loss of telomere function causes several adverse effects, such as genomic instability, aneuploidy and even cancer. It has been reported that tumor tissues express elevated levels of telomerase compared to normal tissues (19). Several parameters can affect telomere and telomerase functions, including oxidative stress, DNA damage, dietary supplementations and environmental/occupational exposures $(20,21)$. The inhibition of telomerase activity is known to be associated with genomic instability, and plays an important role in DNA damage mechanisms and cancer development. It has been demonstrated that the expression of telomerase enzyme protects cells from DNA-damaging events, and it has been shown that this protective function is independent from its telomere synthesis function (22).

In this study, we investigated the DNA-damaging potential of stanozolol and its effects on telomerase activity in stanozolol-treated Sprague-Dawley rats. The role of exercise in DNA damage and telomerase activity was also assessed, as the main target population of stanozolol users are usually physically active individuals.

\section{Materials and methods}

Animal Study. A total of 34 Sprague-Dawley male rats were divided into 5 groups as follows: i) the control group $(n=5)$; ii) the propylene glycol (PG)-treated group $(n=5)$; iii) the stanozolol-treated group $(\mathrm{n}=8)$; iv) the $\mathrm{PG}$-treated group subjected to exercise $(n=8)$; and $v)$ the stanozolol-treated group subjected to exercise $(\mathrm{n}=8)$ (Table I). The mice were injected with $1 \mathrm{ml} / \mathrm{kg}$ PG as a solvent control. Stanozolol $(5 \mathrm{mg} / \mathrm{kg})$ was injected subcutaneously for 28 days for 5 days per week. Swimming was selected as a mode of exercise. The mice were subjected to exercise (swimming) 1 week prior to the commencement of the treatments so that the animals may be able to adapt. During the 28 days of the experiment, the animals subjected to 20 min of swimming for 5 days per week. After 28 days, the animals were lightly anesthetized and euthanized by cervical dislocation. Peripheral blood samples were collected from the tail vein of the rats for the determination of telomerase activity and DNA damage by comet assay. Peripheral blood mononuclear cells (PBMCs) were isolated by using Histopaque 107 (MP Biomedicals LLC, Solon-Ohio, USA). Heparin-treated blood was diluted with an equal volume of PBS and layered carefully over density gradient media and centrifuged at $200 \mathrm{x} \mathrm{g}$ for $3 \mathrm{~min}$ at $4^{\circ} \mathrm{C}$. During centrifugation, cells migrate differentially and layers are formed. PBMCs were retrieved from just above the boundary between plasma and Histopaque. Comet assay and telomerase activity assays were all performed using the PBMCs. Cell viability was examined by the trypan blue exclusion assay before performing comet assay and the viability results were $>90 \%$ for each sample (data not shown).
Table I. Experimental groups in this study.

\begin{tabular}{|c|c|c|}
\hline $\begin{array}{l}\text { Animal } \\
\text { groups }^{\mathrm{a}}\end{array}$ & $\begin{array}{l}\text { No. of } \\
\text { rats }\end{array}$ & Procedures undertaken \\
\hline Group I & 5 & No injection, no exercise \\
\hline Group II & 5 & Subcutaneous injection of $1 \mathrm{ml} / \mathrm{kg} \mathrm{PG}$ \\
\hline Group III & 8 & Subcutaneous injection of $5 \mathrm{mg} / \mathrm{kg}$ stanozolol \\
\hline Group IV & 8 & $\begin{array}{l}\text { Subcutaneous injection of } 1 \mathrm{ml} / \mathrm{kg} \mathrm{PG} \text {, exercise } \\
20 \mathrm{~min} / \text { day, } 5 \text { day/week (swimming) }\end{array}$ \\
\hline Group V & 8 & $\begin{array}{l}\text { Subcutaneous injection of } 5 \mathrm{mg} / \mathrm{kg} \text { stanozolol, } \\
\text { exercise } 20 \mathrm{~min} / \text { day, } 5 \text { day/week (swimming) }\end{array}$ \\
\hline
\end{tabular}

${ }^{\mathrm{a}}$ Group I, control; group II, PG; group III, stanozolol; group IV, PG treatment and exercise; group $\mathrm{V}$, stanozolol treatment and exercise; PG, propylene glycol.

Rat care, handling, and all of the experimental procedures employed were in accordance with the instructions of the Ethics Committee on Animal Experimentation of Istanbul University, HADYEK and approved with no. 2013/100.

Comet assay. The alkaline comet assay was performed as previously descrbibed by Singh et al (23) with slight modifications, as described in Ozcagli et al (24). Each microscopic slide was covered with $0.65 \%$ normal melting agarose (NMA). Histopaque density gradient centrifugation was used for lymphocyte isolation. The isolated cells were mixed with $0.65 \%$ low melting agarose (LMA) and embedded on NMA-covered slides. The slides were incubated overnight in cold lysing solution (1\% Triton X-100 and 10\% DMSO added just before use in $2.5 \mathrm{M} \mathrm{NaCl}, 100 \mathrm{mM} \mathrm{Na}{ }_{2}$ EDTA, $10 \mathrm{mM}$ Tris, pH 10) at $4^{\circ} \mathrm{C}$. Subsequently, an electrophoresis step was performed with (1 $\mathrm{mM} \mathrm{Na}{ }_{2}$ EDTA and $300 \mathrm{mM} \mathrm{NaOH}, \mathrm{pH}$ 13) fresh solution following alkali exposure to $20 \mathrm{~min}$ for DNA unwinding. The electrophoresis step was conducted at $1.6 \mathrm{~V} / \mathrm{cm}$ for $20 \mathrm{~min}(300 \mathrm{~mA})$ at $4^{\circ} \mathrm{C}$. Prior to ethidium bromide (EB) dye staining, the alkali conditions were neutralizated with tris buffer (0.4 M Tris, pH 7.5). All these steps were conducted under dimmed light and the slides were evaluated by one slide reader, blindly. One hundred cells per slide were analyzed under a fluorescence microscope equipped with an excitation filter of $546 \mathrm{~nm}$ and a barrier filter of $590 \mathrm{~nm}$ (Olympus BX53; Olympus Corp., Tokyo, Japan). The results were evaluated using the Comet Assay IV image analysis system (Comet Assay IV; Perceptive Instruments Ltd., Suffolk, UK) in order to score DNA damage. Tail intensity data was selected for the evaluation of DNA damage.

Telomerase activity assay. The determination of telomerase activity in the PBMCs was performed quantitatively using the teloTAGGG telomerase PCR ELISA PLUS kit (Roche Diagnostic GmbH, Mannheim, Germany). The kit protocol was followed for telomerase activity assessment as previously described (25). A total of $2 \times 10^{5}$ cells were transferred to a PCR tube for sample preparation for telomerase activity assay. Following centrifugation at 3,000 $\mathrm{x} g$ for $10 \mathrm{~min}$, the supernatant was carefully removed and the pellets were collected. The assay 
Table II. Expression of tail intensity and telomerase activity (\%) in the peripheral blood mononuclear cells from the rats in the experimental groups.

\begin{tabular}{|c|c|c|c|c|c|}
\hline Assay & $\begin{array}{c}\text { Exposure }^{\mathrm{a}} \\
\text { group }\end{array}$ & $\begin{array}{l}\text { No. } \\
\text { of rats }\end{array}$ & Mean \pm standard deviation & Median & Kruskal-Wallis \\
\hline \multirow[t]{5}{*}{ Tail intensity } & Group I & 5 & $4.0 \pm 0.5$ & 4.3 & \multirow{5}{*}{$\begin{array}{l}\chi^{2}=10.56 \\
\mathrm{df}=4 \\
\mathrm{P}=0.032\end{array}$} \\
\hline & Group II & 5 & $4.8 \pm 2.8$ & 3.9 & \\
\hline & Group III & 8 & $5.8 \pm 1.6$ & 0.5 & \\
\hline & Group IV & 8 & $5.1 \pm 1.7$ & 4.85 & \\
\hline & Group V & 8 & $3.5 \pm 0.6$ & 3.6 & \\
\hline \multirow[t]{5}{*}{ Telomerase activity (\%) } & Group I & 5 & $100.0 \pm 19.4$ & 93.3 & \multirow{5}{*}{$\begin{array}{l}\chi^{2}=24.65 \\
\mathrm{df}=4 \\
P<0.001\end{array}$} \\
\hline & Group II & 5 & $474.9 \pm 358.2$ & 597.0 & \\
\hline & Group III & 8 & $1,851.4 \pm 319.2$ & $1,909.2$ & \\
\hline & Group IV & 8 & $193.4 \pm 27.9$ & 196.5 & \\
\hline & Group V & 8 & $328.7 \pm 183.1$ & 240.0 & \\
\hline
\end{tabular}

${ }^{\mathrm{a}}$ Group I, control; group II, PG; group III, stanozolol; group IV, PG treatment and exercise; group V, stanozolol treatment and exercise.

principle was consisting of two steps. The first step included the addition of telomeric repeats (TTAGGG) to the $3^{\prime}$ end of biotin-labelled primers and product amplification by PCR. The second step consisted of ELISA reaction.

Statistical analysis. The mean, standard deviation (SD) and the median were used for the expression of tail intensity. Telomerase activity was expressed in proportion of the control group (\%). The non-parametric Kruskal-Wallis test was applied for comparing the results of comet assay. The same test was also applied for the comparison of expressed telomerase activity. Non-parametric post-hoc comparisons were assessed using Dunn's test. Box and whisker plots were used for the graphical representation of the data. IBM SPSS Statistical software 21.0 (IBM SPSS, Armonk, NY, USA) was used for statistical analysis. A value of $\mathrm{P}<0.05$ was set for accepting (or rejecting) the null hypothesis and was considered to indicate a statistically significant difference.

\section{Results}

The results of tail intensity and the telomerase activity (\%) in the experiental groups (exposed and controls) are shown in Table II. The analysis revealed that tail intensity differed significantly between groups $(\mathrm{P}=0.032)$, while differences in telomerase activity were also significant $(\mathrm{P}<0.001)$. It can be seen that the highest values were observed in group III for both comet assay and telomerase activity assessment $(5.8 \pm 1.6$ and $1851.4 \pm 319.2$, respectively) in comparison to the other groups (I, II, IV and V). All other values ranged between $3.5 \pm 0.6$ (group V) to 5.1 \pm 1.7 (group IV) for tail intensity, while the lowest telomerase activity (\%) was 100 \pm 19.4 (group I).

According to the results of the pair wise comparison of tail intensity based on Dunn's test, was observed that the cells from the animals in group $\mathrm{V}$ exhibited significantly lower levels of tail intensity compared to those from the animals in group IV $(\mathrm{P}=0.025)$ and group III $(\mathrm{P}=0.002)$. Our results revealed that telomerase activity $(\%)$ differed significantly
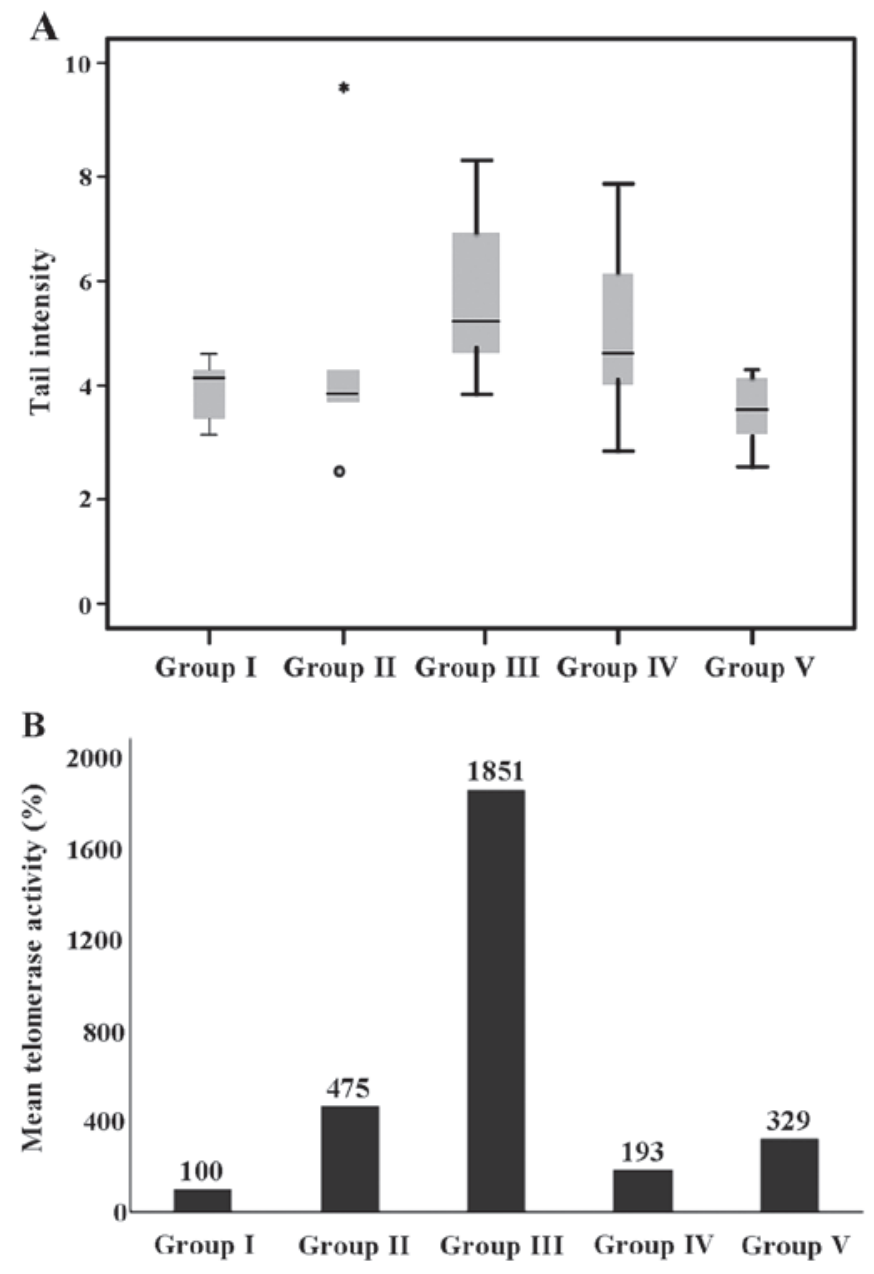

Figure 1. (A) Tail intensity and (B) telomerase activity (\%) of stanozolol and propylene glycol (PG)-exposed groups. Group I, control; group II, PG; group III, stanozolol; group IV, PG treatment and exercise; group V, stanozolol treatment and exercise. Extreme outliers are indicated by an asterisk (*) and circle (o).

when group III was compared with the other groups (group I, $\mathrm{P}<0.001$; group II, $\mathrm{P}=0.016$; group IV, $\mathrm{P}<0.001$; and group $\mathrm{V}$, 
$\mathrm{P}=0.012)$. Group I exhibited a significant difference compared with the other groups apart from group IV $(\mathrm{P}=0.121)$ Group II did exhibit a significant difference compared to group $\mathrm{V}(\mathrm{P}=0.292)$.

The expression of tail intensity is also presented in a box and whisker plot (Fig. 1A), while the telomerase expression (\%) is presented in a bar chart (Fig. 1B).

\section{Discussion}

Apart from causing several adverse health effects, the DNA-damaging effects of different AAS have been studied using various techniques. Stanozolol is a widely abused steroid, particularly for the purposes of doping and improving physical status. Very limited information is available regarding the DNA-damaging effects of stanozolol, while a positive correlation between exposure to nandrolone and DNA damage has been determined $(14,26,27)$. In previous studies, a significant increase in DNA damage was determined in blood, liver, bone marrow, brain and testicle cells in experimental animals exposed to high doses of nandrolone $(14,28)$. In addition, in a review, Boettcher et al reported increased DNA damage with trenbolone treatment in zebrafish embryos via comet assay and the micronucleus test; however, this increase was not observed with high-dose trenbolone treatment (29 and refs therein). Our results are in accordance with the findings of these studies, demonstrating the DNA-damaging effects of stanozolol. Although exercise has been defined as a key element of a healthy lifestyle, many controversial results have also been published (30-32). Exercise-induced DNA damage has been documented in several studies in physically active/overtrained individuals or even in experimental animals by several techniques (33-35). According to our search, there was only one study available in the literature investigating stanozolol and exercise-induced genotoxicity. Martins et al demonstrated that the administration of anabolic steroids (decadurabulin and winstrol) induced chromosomal damage, which was not associated with physical activity (36). The results of our study indicated increased DNA damage in the exercise-exposed control group (PG and exercise group); however, stanozolol played a protective role in exercise-induced DNA damage in the stonozolol-exposed groups.

It is well-documented that telomerase activity plays a role in DNA damage and repair mechanisms. In addition, several pathways have been defined regarding the mechanisms of the effects of AAS on telomerase activity $(20,37,38)$ Nourbakhsh et al demonstrated that testosterone and androstenedione both increased cell viability by upregulating telomerase activity in the OVCAR-3 cell line. This upregulation was triggered by the PI3K/Akt pathway. Quantitative PCR analyses demonstrated that the hTERT mRNA levels were significantly increased with exposure to testosterone and androstenedione (37). Zhou et al demonstrated that the testosterone derivative, estrogen, increased telomerase activity via the mitogen-activated protein kinase (MAPK) pathway in endometrial cancer cells (39). Geier et al reported significantly increased telomerase activity and gene expression with testosterone and dihydrotestosterone (DHT) treatment (40). In addition, androgen exposure has previously been reported to increase telomerase activity by higher TERT mRNA levels in PBMCs (38). According to our search, there was no study available in the literature on the effects of stanozolol on telomerase activity. There is limited evidence regarding the genotoxicity of stanozolol, while there are several studies available on the effects of other AAS. We demonstrated that stanozolol induced telomerase activity and this increase may be associated with DNA damage.

The effects of exercise on telomerase activity primarily depend on the amount of exercise and cell types. Increased telomerase enzyme activity in skeletal muscles with exercise has been shown by Ludlow et al (20). Exercise may reduce telomere shortening-associated aging; however, extreme amounts of exercise have been reported to shorten telomeres. Furthermore, the effects of exercise on telomeric genes and miRNA regulation provides insight into the mechanistic association between exercise, telomeres and health (41). Mosallanezhad et al demonstrated significantly increased levels of telomerase activity and improved telomere length in sedentary women who performed high-intensity interval training (42). In this study, we observed a decrease in telomerase activity in stanozolol-treated rats subjected to exercise. Our results are in line with those of previous findings regarding the effects of exercise on telomerase activity.

In conclusion, in this study, an increase in DNA damage was detected with exercise; however, it was observed that exercise did not have a significant DNA-damaging effect in the steroid treated group. Therefore, the preventive role of stanozolol should be taken into consideration for the interpretation of these results for physically active or overtrained individuals. There is a need for further studies in order to clarify the preventive role of stanozolol in physical activity in terms of DNA damage. Thus, the effects of exercise warrant further clarifications for the determination of the genotoxic effects of stanozolol and the mechanisms responsible for stanozolol-induced DNA damage. The DNA-damaging effects of stanozolol may be mediated through alterations in telomerase activity. However, further studies are required in order to fully elucidate the association between stanozolol use, exercise and DNA damage.

\section{Acknowledgements}

The present study was supported by Istanbul University Scientific Research Projects Department (project no. 39101-21899).

\section{References}

1. Sagoe D, McVeigh J, Bjørnebekk A, Essilfie MS, Andreassen CS and Pallesen S: Polypharmacy among anabolic-androgenic steroid users: A descriptive metasynthesis. Subst Abuse Treat Prev Policy 10: 12, 2015.

2. Tsitsimpikou C, Tsarouhas K, Spandidos DA and Tsatsakis AM: Detection of stanozolol in the urine of athletes at a pg level: The possibility of passive exposure. Biomed Rep 5: 665-666, 2016.

3. Darke S, Torok M and Duflou J: Sudden or unnatural deaths involving anabolic-androgenic steroids. J Forensic Sci 59: 1025-1028, 2014

4. Hartgens F and Kuipers H: Effects of androgenic-anabolic steroids in athletes. Sports Med 34: 513-554, 2004.

5. Büttner A and Thieme D: Side effects of anabolic androgenic steroids: Pathological findings and structure-activity relationships. Handb Exp Pharmacol 195: 459-484, 2010.

6. Kicman AT: Pharmacology of anabolic steroids. Br J Pharmacol 154: 502-521, 2008 . 
7. Barbosa Dos Santos G, Machado Rodrigues MJ, Goncalves EM, Cintra Gomes Marcondes MC and Areas MA: Melatonin reduces oxidative stress and cardiovascular changes induced by stanozolol in rats exposed to swimming exercise. Eurasian J Med 45: 155-162, 2013.

8. Beg T, Siddque YH and Afzal M: Chromosomal damage induced by androgenic anabolic steroids, stanozolol and trenbolone in human lymphocytes. Adv Environ Biol 1: 39-43, 2007.

9. Helfman T and Falanga V: Stanozolol as a novel therapeutic agent in dermatology. J Am Acad Dermatol 33: 254-258, 1995.

10. Shalizar Jalali A, Najafi G, Hosseinchi M and Sedighnia A Royal Jelly alleviates sperm toxicity and improves in vitro fertilization outcome in Stanozolol-treated mice. Iran J Reprod Med 13: 15-22, 2015.

11. Moeller BC, Sams RA, Guingab-Cagmat JD, Szabo NJ Colahan P and Stanley SD: Pharmacokinetics of stanozolol in Thoroughbred horses following intramuscular administration. J Vet Pharmacol Ther 36: 201-204, 2013.

12. World Anti-doping Agency: 2016 List of Prohibited Substances and Methods. https://www.wada-ama.org/. Accessed September 16, 2016.

13. Deshmukh NI, Zachar G, Petróczi A, Székely AD, Barker J and Naughton DP: Determination of stanozolol and 3'-hydroxystanozolol in rat hair, urine and serum using liquid chromatography tandem mass spectrometry. Chem Cent J 6: 162, 2012

14. do Carmo CA, Gonçalves ALM, Salvadori DMF and Maistro EL: Nandrolone androgenic hormone presents genotoxic effects in different cells of mice. J Appl Toxicol 32: 810-814, 2012.

15. Torres-Bugarín O, Covarrubias-Bugarín R, Zamora-Perez AL, Torres-Mendoza BMG, García-Ulloa M and Martínez-Sandoval FG: Anabolic androgenic steroids induce micronuclei in buccal mucosa cells of bodybuilders. Br J Sports Med 41: 592-596, discussion 596, 2007.

16. Hana HY, Khalil WK, Elmakawy AI and Elmegeed GA Androgenic profile and genotoxicity evaluation of testosterone propionate and novel synthesized heterocyclic steroids. J Steroid Biochem Mol Biol 110: 284-294, 2008.

17. Ho SM and Roy D: Sex hormone-induced nuclear DNA damage and lipid peroxidation in the dorsolateral prostates of Noble rats. Cancer Lett 84: 155-162, 1994

18. Ragnotti G, Presta M, Maier JAM, Rusnati M, Mazzoleni G, Legati F, Chiesa R, Braga M and Calovini D: Critical role of gonadal hormones on the genotoxic activity of the hepatocarcinogen DL-ZAMI 1305. Cancer Lett 36: 253-261, 1987.

19. Liu S, Qi Y, Ge Y, Duplessis T, Rowan BG, Ip C, Cheng H, Rennie PS, Horikawa I, Lustig AJ, et al: Telomerase as an important target of androgen signaling blockade for prostate cancer treatment. Mol Cancer Ther 9: 2016-2025, 2010.

20. Ludlow AT, Ludlow LW and Roth SM: Do telomeres adapt to physiological stress? Exploring the effect of exercise on telomere length and telomere-related proteins. Biomed Res Int 2013: 601368, 2013.

21. Zhu H, Guo D, Li K, Pedersen-White J, Stallmann-Jorgensen IS, Huang Y, Parikh S, Liu K and Dong Y: Increased telomerase activity and vitamin D supplementation in overweight African Americans. Int J Obes 36: 805-809, 2012.

22. Fleisig HB, Hukezalie KR, Thompson CAH, Au-Yeung TTT, Ludlow AT, Zhao CR and Wong JMY: Telomerase reverse transcriptase expression protects transformed human cells against DNA-damaging agents, and increases tolerance to chromosomal instability. Oncogene 35: 218-227, 2016.

23. Singh NP, McCoy MT, Tice RR and Schneider EL: A simple technique for quantitation of low levels of DNA damage in individual cells. Exp Cell Res 175: 184-191, 1988.

24. Ozcagli E, Sardas S and Biri A: Assessment of DNA damage in postmenopausal women under hormone replacement therapy. Maturitas 51: 280-285, 2005.

25. Tsitsimpikou C, Tzatzarakis M, Fragkiadaki P, Kovatsi L, Stivaktakis P, Kalogeraki A, Kouretas D and Tsatsakis AM: Histopathological lesions, oxidative stress and genotoxic effects in liver and kidneys following long term exposure of rabbits to diazinon and propoxur. Toxicology 307: 109-114, 2013.
26. Ahmed MA: Amelioration of nandrolone decanoate-induced testicular and sperm toxicity in rats by taurine: Effects on steroidogenesis, redox and inflammatory cascades, and intrinsic apoptotic pathway. Toxicol Appl Pharmacol 282: 285-296, 2015.

27. Pozzi R, Fernandes KR, de Moura CFG, Ferrari RAM, Fernandes KPS, Renno ACM and Ribeiro DA: Nandrolone decanoate induces genetic damage in multiple organs of rats. Arch Environ Contam Toxicol 64: 514-518, 2013.

28. Hemmersbach P and Grosse J: Nandrolone: A multi-faceted doping agent. Handb Exp Pharmacol 195: 127-154, 2010.

29. Boettcher M, Kosmehl T and Braunbeck T: Low-dose effects and biphasic effect profiles: Is trenbolone a genotoxicant? Mutat Res 723: 152-157, 2011.

30. Spanidis Y, Goutzourelas N, Stagos D, Mpesios A, Priftis A, Bar-Or D, Spandidos DA, Tsatsakis AM, Leon G and Kouretas D: Variations in oxidative stress markers in elite basketball players at the beginning and end of a season. Exp Ther Med 11: 147-153, 2016.

31. Baltaci SB, Mogulkoc R and Baltaci AK: Resveratrol and exercise (Review). Biomed Rep 5: 525-530, 2016.

32. Powers SK and Hogan MC: Exercise and oxidative stress. J Physiol 594: 5079-5080, 2016

33. Gandhi G and Chopra G: DNA damage in peripheral blood leukocytes of physically active individuals as measured by the alkaline single cell gel electrophoresis assay. Environ Mol Mutagen 50: 291-303, 2009.

34. Pereira BC, Pauli JR, Antunes LM, de Freitas EC, de Almeida MR, de Paula Venâncio V, Ropelle ER, de Souza CT, Cintra DE, Papoti M, et al: Overtraining is associated with DNA damage in blood and skeletal muscle cells of Swiss mice. BMC Physiol 13: 11, 2013.

35. Siu PM, Pei XM, Teng BT, Benzie IF, Ying M and Wong SH: Habitual exercise increases resistance of lymphocytes to oxidant-induced DNA damage by upregulating expression of antioxidant and DNA repairing enzymes. Exp Physiol 96: 889-906, 2011.

36. Martins RA, Gomes GA, Aguiar O Jr, Medalha CC and Ribeiro DA: Chromosome damage and cytotoxicity in oral mucosa cells after 2 months of exposure to anabolic steroids (decadurabolin and winstrol) in weight lifting. Steroids 75: 952-955, 2010.

37. Nourbakhsh M, Golestani A, Zahrai M, Modarressi MH, Malekpour Z and Karami-Tehrani F: Androgens stimulate telomerase expression, activity and phosphorylation in ovarian adenocarcinoma cells. Mol Cell Endocrinol 330: 10-16, 2010.

38. Calado RT, Yewdell WT, Wilkerson KL, Regal JA, Kajigaya S, Stratakis CA and Young NS: Sex hormones, acting on the TERT gene, increase telomerase activity in human primary hematopoietic cells. Blood 114: 2236-2243, 2009.

39. Zhou C, Steplowski TA, Dickens HK, Malloy KM, Gehrig PA, Boggess JF and Bae-Jump VL: Estrogen induction of telomerase activity through regulation of the mitogen-activated protein kinase (MAPK) dependent pathway in human endometrial cancer cells. PLoS One 8: e55730, 2013.

40. Geier R, Adler S, Rashid G and Klein A: The synthetic estrogen diethylstilbestrol (DES) inhibits the telomerase activity and gene expression of prostate cancer cells. Prostate 70: 1307-1312, 2010.

41. Chilton WL, Marques FZ, West J, Kannourakis G, Berzins SP, $\mathrm{O}$ 'Brien BJ and Charchar FJ: Acute exercise leads to regulation of telomere-associated genes and microRNA expression in immune cells. PLoS One 9: e92088, 2014.

42. Mosallanezhad Z, Nikbakht H, Gaeini AA and Gholami M: The effect of high-intensity interval training on telomere length of leukocytes in sedentary young women. Advances in Environmental Biology 841-846, 2014. 